\title{
Power Translator version 2.0: logiciel d'aide à la traduction
}

Globalink, 1994

Lesley Graham

\section{(2) OpenEdition}

Journals

Electronic version

URL: http://journals.openedition.org/asp/4122

DOI: $10.4000 /$ asp.4122

ISSN: 2108-6354

\section{Publisher}

Groupe d'étude et de recherche en anglais de spécialité

Printed version

Date of publication: 1 December 1994

Number of pages: 259-262

ISSN: 1246-8185

\section{Electronic reference}

Lesley Graham, « Power Translator version 2.0: logiciel d'aide à la traduction », ASp [Online], 5-6 | 1994, Online since 20 December 2013, connection on 22 September 2020. URL : http:// journals.openedition.org/asp/4122; DOI : https://doi.org/10.4000/asp.4122

This text was automatically generated on 22 September 2020

Tous droits réservés 


\section{Power Translator version 2.0: logiciel d'aide à la traduction}

Globalink, 1994

Lesley Graham

\section{REFERENCES}

Power Translator version 2.0: logiciel d'aide à la traduction. Globalink, 1994.

\section{EDITOR'S NOTE}

The title of the book review in the paper publication was “'That Does Not Walk ++Bien', The trials and tribulations of an automatic translation programme".

1 As I do a lot of revision/rewriting/translation work for colleagues in the science departments of our University, imagine my joy and relief when we received a piece of software that termed itself a Power Translator (PT). ${ }^{1}$ I looked more closely at the box. An example of the prowess of PT had been highlighted by the manufacturers. The English

When I light the candles, the light fills the room had been rendered (by whom or what, I wondered) as

Quand j'allume les bougles, la lumière remplit la pièce

2 Yes, "bougles". A mere typo, perhaps, but witness to some inattention. However, all would be well with a software widely advertised in the computer monthlies. Closer scrutiny, however, revealed something more worrying: "formes verbales conjuguées" had become "verb conjunctions". Which language had been translated here? Presumably this was French to English, although why would Globalink be translating in this direction? I therefore embarked on my appraisal of PT with some incomprehension and a modicum of diffidence. 
3 What I found can be summarised as such; there is good news and bad. Since the good will take up precious little space, you'll get it now. The manufacturers state that it is easy to use. It is. The software and accompanying manual allows anybody with minimal computer literacy to start translating five minutes after initialisation, thanks to the two basic dictionaries included.

That was it. Now for the bad.

4 The claim is that PT "produces draft translations that you edit into final form". If you are a translator, it "saves you time". If you are a teacher of French, PT is "a valuable teaching tool" since it "helps students learn French without drudgery". And if you are in business, "PT gives you the ability to communicate with French companies". ${ }^{2}$ I would maintain that it can do precious little of any of the above. Judge for yourself from this first example from French to English:

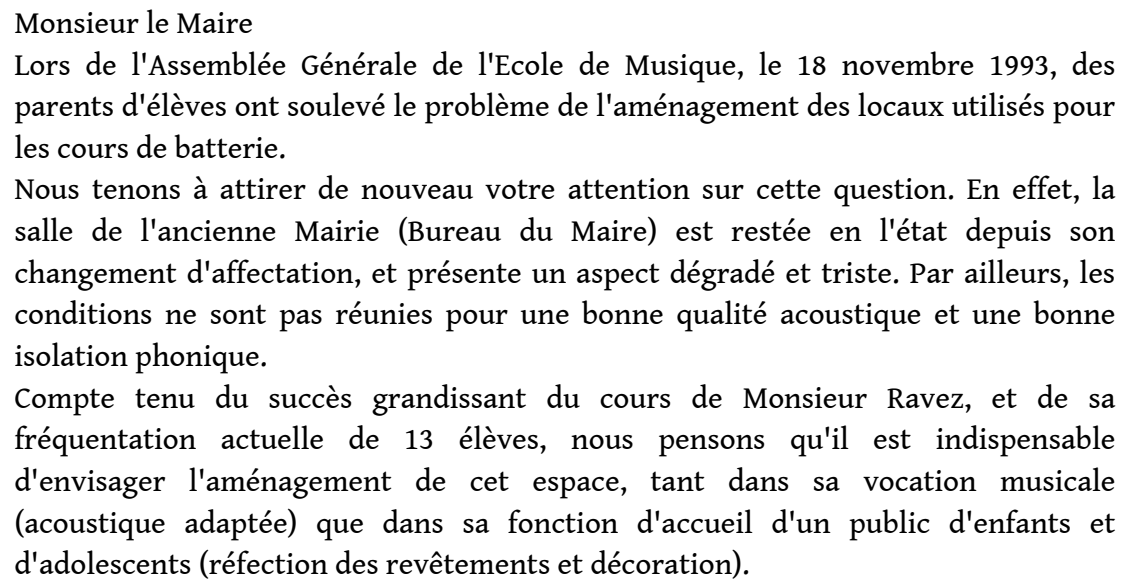

5 A fairly bland text, and certainly something that PT could reasonably be expected to manage ${ }^{3}$ if it is to be worth anything. Now read on.
Sir the Mayor
During the General Assembly of School of Music, 18 November 1993, ++parents of pupils have raised the problem of the adjustment of premises used for courses of battery.
We hold to attract new your attention on this question. Indeed, the hall of the ancient Mayoralty (Bureau of the Mayor) has remained in the state since its change of allocation, and presents an aspect degraded and sad. Furthermore, conditions are not united for a good acoustic quality and a good insulation @@phonique.
Held account of the success growing the course of Sir Dawdle, and its current company of 13 pupils, we think that it is indispensable to envisage the adjustment of this space, so in its musical vocation (adapted acoustics) that in its function of welcome of a children and adolescent public (coatings and decoration repairing).

The signs “++" and "@@” indicate that the software did not recognise these words and therefore did not attempt to translate them. All the rest, however, can only be supposed by the user unfamiliar with the target language to be correct. The rendition speaks for itself, but some particular comments are required. How can a tool purporting to translate "at up to $90 \%$ accuracy" not be programmed to recognise as frequent a structural element as "compte tenu de" or "tant...que..."? Or for that matter a verbal group like "tenir à faire quelque chose"? ${ }^{4}$ And goodness only knows how Sir Dawdle got in on the act! 
7 Dismayed but not deterred, I decided to try again, this time from English to French. Already I had misgivings so I decided to lend PT a hand; i.e., give it something really simple, or at least apparently so. This is what happened:

The fight against AIDS can only take place by preventive action on behaviour. In Africa almost all social groups are exposed and the potential development of the epidemic is extremely great. Information and education campaigns until now have either been aimed at the masses or targeted at very specific groups: prostitutes, truck drivers, taxi drivers, etc.

...which gave the following:

Le combat contre DES AIDES peut seulement avoir lieu par l'action préventive sur le comportement. Dans Afrique presque tous groupes sociaux sont exposés et le développement potentiel de l'épidémie est extrêmement grand. Les campagnes d'instruction et information jusqu'à maintenant ont l'un ou l'autre été visées aux masses ou visées aux groupes très spécifiques: les prostituées, conducteurs de camion, conducteurs de taxi, etc.

8 True, to the experienced eye, there is some improvement here. However, the question still stands of how we are to move from this rough draft to an acceptable version. On this point, the manual is evasive. The user is told that the draft can be improved if a few tips are kept in mind. In an edifying section of potted hints, ${ }^{5}$ he is succinctly informed that if he wishes to improve the quality of the translation, he can do three things: edit the source document; update the personal dictionaries; and edit the translated document. The manual would have the user "correct spelling and grammatical errors and poor punctuation, split longer sentences into shorter ones, simplify awkward or ambiguous phrasing, and add missing pronouns and prepositions"...presumably by the grace of God! Some particular shortcomings, such as the inability to handle gerunds, prove especially irritating.

9 The deception - perhaps truly unconscious on the part of the manufacturer but no less unforgivable- reaches its zenith in a choice little sub-section dealing with incorrect verb tense. The user is given two examples of typical mistranslations that PT will make. "I read the book yesterday" and "Hier, je suis allé au marché" become respectively "Je lis le livre hier" and "Yesterday, I have gone to the market". He is then shown how to correct them himself by editing. The deception is two-fold. First, the use of a temporal marker such as "yesterday" opens the way nicely for the paradigm concerning the simple past; yet the present reader will be only too well aware that this is an easy error to correct for anyone familiar with basic English. Second, and certainly more serious, the claim made in the introduction to the manual that PT "finds words and phrases in its dictionaries, then translates the entire sentence as a whole", is apparently unfounded. Otherwise, a fundamental grammatical rule would have been consulted and the verb "read" would have been translated correctly. In other words, the programme is unable to render accurately an association of semantic units within a sentence.

10 Out of curiosity, I decided to consult the list of semantic units in English. The last fourteen in the alphabetical list ${ }^{6}$ are revealing in their apparent arbitrariness. How were they chosen? Arguably, some do not even constitute semantic units.

11 Other anecdotes abound. "Deux paquets de cigarettes" and "deux meutes de loups" translate as "two parcels of cigarettes" and "two packs of wolves" respectively, an amusing mistranslation of the former if you are in the know, but more serious if you are not and work in the import-export sector. 
12 Which brings us to the crunch issue. There is a clear discrepancy between what the programme claims it is to be able to do and what in fact it can manage. And there is a diametrical opposition between what an unsuspecting user is supposed to do to obtain an edited translation and what a professional translator would do if he/she were to use the programme. The former does not possess the specialised knowledge of the target language to be able to judge whether the draft is satisfactory or not, while the latter would never waste his/her time patching up a third-rate version. Experienced translators normally bypass the phase of the first written draft with a dictated version, since they, unlike the programme, possess the cognitive skills to handle complex semantic units within and between sentences. The great danger, however, is to the former who, in all good faith, is likely to buy such software and trust in it. One can only fear that there has been some jumping on the bandwagon in the production and marketing of this programme; indeed, the addition of an English voice synthesis programme requiring the listener to be reading the text in order to understand it only serves to reinforce this disagreeable impression.

13 As a parting shot, I thought it might be appropriate to get PT to translate itself, i.e., the blurb in the preface to the manual. First, here's the English:

What you must know

Before using Power Translator, you must know how to perform standard operations common to all Macintosh programs. If you are comfortable using a Macintosh word processing program such as MacWrite or Microsoft Word, you already know enough to use Power Translator.

And this is what the programme came up with:

Ce que vous devez connaître

Avant utilisant Le traducteur Assisté, vous devez connaître comment exécuter des opérations ordinaires communes à tout @@Macintosh programmes. Si vous êtes confortables utilisant un @@Macintosh mot-traitement programme tel que @@MacWrite ou @@Microsoft Mot, vous connaissez déjà assez employer Le traducteur Assisté.

Finally, the French as printed in the manual:

Ce que vous devez savoir.

Avant d'utiliser le Power Translator, il faut que vous sachiez comment exécuter les opérations standard que l'on trouve dans la plupart des programmes Macintosh. Si vous n'avez aucun problème pour utiliser Macwrite ou Microsoft Word, vous en savez déjà assez pour utiliser le Power Translator.

14 Tantamount, surely, to a vote of no confidence. Mesdames et Messieurs, nos vivons une époque moderne..

\section{BIBLIOGRAPHY}

O'Brien, Sharon. 1994. "Sublanguage, text type and machine translation". In Applications and Implications of Current LSP Research/Proceedings of the 9th European Symposium on LSP. Bergen: Fagbokforlaget, 832-839. 


\section{NOTES}

1. Globalink (9302 Lee Highway,Fairfax, VA 22031, USA) distribué en France par Softissimo, 129 bd de Sébastopol, 75002 Paris (existe également en version allemand/anglais et espagnol/ anglais). Globalink fournit également ses "draft quality translations" par courrier électronique sur Internet : tous renseignements à <info@glnk.com>.

2. The manual is itself translated into French. The reference to French companies appears as " sociétés françaises", and continues with the sentence, "Même si vous n'avez jamais parlé français, vous pouvez...", an almost laughable error of inattention. (The underlining is the present author's).

3. In view of the immense lexical variety of any modern language, attempts to improve machine translation have centred on the concept of sublanguage i.e., the specific limited register of a specialty such as technical instructions for a particular machine. However, this extract from a letter cannot reasonably be said to contain items situated outside the lexis of everyday life.

4. For a succinct discussion of the capabilities of machine translation, see O'Brien (1994).

5. Power Translator version 2.0, User's Guide, pp. 34-38.

6. working breakfast, working lunch, worldwide sea level, would you like, would you like a cigarette, would you like to come out with me, would you like to go to a dance, wrongly, wrought iron, yearly interest, you're welcome, yours faithfully, zip, zip code

\section{AUTHORS}

\section{LESLEY GRAHAM}

Université Bordeaux 2. lesley.graham@u-bordeaux2.fr 